\title{
Employment, Income Distribution and Economic Growth in Seven Small Open Economies
}

\author{
Gary S. Fields
}

Cornell University

The Economic Journal (March 1984), 94, 74-83 
Resurgent interest has been manifested among development economists in trickle-down, i.e., the view that the more rapid the rate of economic growth, the more rapid the improvement in employment and income distribution. ${ }^{1}$ Throughout this paper, the term 'income distribution' will refer to the location and dispersion of the pattern of incomes, i.e., to 'absolute incomes and poverty' and to 'relative income inequality'. Empirical evidence supports trickle-down in some cases, but the evidence is contrary to trickle-down in others. The evidence from my own study of six countries' experiences ${ }^{2}$ is summarised in Tables 1 and 2.

Insert Table 1 Here

Insert Table 2 Here

These data indicate:

(1) A high rate of economic growth is neither necessary nor sufficient for inequality to decline.

(2) A high rate of economic growth is neither necessary nor sufficient for poverty to decline.

(3) Inequality change and poverty change need not go in the same direction in a given country. In particular, poverty may decrease while inequality increases.

The evidence in the preceding paragraph makes clear that changes in poverty and inequality depend upon more than the rate of economic growth. A good working hypothesis is

\footnotetext{
${ }^{1}$ Examples of forceful statements are Galenson (1979), Crosswell (1981) and Chow and Papanek (1981).

${ }^{2}$ Fields (1980, Tables 7.1 and 7.2).
} 
that the character of economic growth also matters. While many aspects of the character of economic growth may be explored, the two that I examine in this paper are the trade orientation of a country (whether export- oriented or internally-oriented) and the wage policy pursued (whether public policy promotes market-clearing wage rates or higher-than-market-clearing wages). I contend in this paper that the effects of trade policy and wage policy are interrelated and present evidence from seven small open economies_-Barbados, Hong Kong, Jamaica, Korea, Singapore, Taiwan and Trinidad and Tobago - to support this view.

I. Growth, Employment, and Income Distribution in Seven Economies

The macroeconomic records of Hong Kong, Korea, Singapore, and Taiwan are wellknown. Real per capita income grew in the 1960s and 1970s by at least $7 \%$ per annum in each country. Exports grew at annual rates ranging from $3 \%$ in Hong Kong to more than $13 \%$ in Korea, so that today the four countries' exports are about equal. Major structural shifts took place in the locus of economic activity. Korea, Singapore, and Taiwan exhibited relative growth of manufacturing and relative decline of agriculture. In Hong Kong, where the growth of manufacturing had occurred in the 1950s, the most important structural change in the 1960s and 1970s was the growing contribution of finance and commerce to national income, reflecting Hong Kong's embarkation on the next stage of development.

In Barbados, Jamaica, and Trinidad and Tobago, the growth records are less favourable. Growth rates there averaged only 1-2\% per annum in per capita terms. All three countries suffered serious recessions in the early 1970s. Barbados and Trinidad and Tobago recovered and grew at real per capita rates ranging from 2 to $7 \%$ in the latter 1970s and early 1980s. Jamaica, 
however, continued to slide, registering a cumulative decline in real per capita GNP of $26 \%$ between 1973 and the present.

What were the micro aspects of growth, or in Jamaica's case, economic decline? Table 3 summarises the evidence on five micro aspects, showing that rapid economic growth in the four East Asian economies was accompanied by marked improvements in employment and income distribution conditions, whereas in the three Caribbean economies, improvements were more modest.

\section{Insert Table 3 Here}

Unemployment. ${ }^{1}$ All four Asian economies have passed the turning point and moved out of the stage of labour surplus. Unemployment rates today are 4-3\% in Hong Kong, 4-1 \% in Korea, 3-1 \% in Singapore, and $1 * 3 \%$ in Taiwan. These rates are low by a number of standards: these countries' own earlier unemployment rates, the unemployment rates in other developing economies today, and the unemployment rates in advanced economies (cf., unemployment of 10$12 \%$ in the United States and Great Britain).

By contrast, unemployment rates are high in the three Caribbean economies under examination. In Barbados and Trinidad and Tobago, unemployment is in the neighbourhood of $12-13 \%$, the same as it was around 1970. In Jamaica unemployment has been rising, and is now

\footnotetext{
${ }^{1}$ The relevance of the unemployment rate as an indicator of labour market performance in a developing country context is sometimes questioned on the grounds that the poor need to work if they are to stay alive. This point has merit, but it is also true that a falling unemployment rate may well be signalling growth or deterioration of job opportunities. The latter would appear to be the case in the East Asian economies and Jamaica, respectively.
} 
on the order of $30 \%$ of the labour force. The adjective most frequently used to describe Jamaica's unemployment problem is 'explosive'.

Employment Composition. Not only has the rate of unemployment fallen but the composition of employment has improved in all four Asian economies. Take first the industrial composition of employment. Agriculture is the employment sector with the lowest wages. The proportion of workers employed in agriculture has fallen in Korea, Singapore, and Taiwan; in each of those cases, the proportion employed in manufacturing has risen, and wages are higher in manufacturing than in agriculture. In Hong Kong, the industrial mix of employment has shifted in favour of finance and commerce - both relatively high paying activities. Next consider occupation. In each economy, the proportion of the non-agricultural labour force in white collar and skilled blue collar occupations is on the increase and the proportion in lower occupational grades is on the decline. Third, take activity status (i.e. the type of employment: regular employee, casual worker, unpaid family worker, own account worker, or self-employed). Economic development typically is marked by rising proportions of workers employed as regular employees and smaller proportions in the other activity categories. Indeed, such improvements are registered in all four economies. Finally, upgrading by education is another indicator of development. Each country's labour force is better educated now.

For the Caribbean countries, the evidence is less complete, but the information we do have indicates some improvements in the types of jobs people hold. As in the Asian economies, agriculture diminished as a fraction of total employment in Barbados and in Trinidad and Tobago; but in Jamaica, agriculture's share held constant. The occupational mix of employment improved in Barbados and Jamaica, but not in Trinidad and Tobago. The educational mix of the 
labour force improved in Jamaica and Trinidad and Tobago; no evidence is available for Barbados.

Real Wages. Real wages have been rising in all four Asian economies, in some cases paralleling the growth of GNP. The highest real wage growth occurred in Taiwan. Wage growth of nearly the same magnitude was registered in Korea. Singapore had the lowest wage growth as a result of deliberate government wage policy holding wages down. Overall, those who were employed in the four Asian economies earned considerably more for their labour than did workers a generation ago.

In the Caribbean economies, the evidence goes back less far - at most a decade. Real wage gains were registered in Trinidad and Tobago, but in Jamaica, real wages declined, matching the rate of decline in GNP as a whole.

Poverty. It is out of the question to think of constructing internationally comparable poverty lines. However, using an absolute poverty line appropriate to each country's level of income, we find that in the four Asian economies, absolute poverty fell impressively: by more than half in each. Alas, in the Caribbean, it was otherwise. We have no data for Barbados, but in Trinidad and Tobago, the incomes of the poorest quartile and poorer half stagnated, and in Jamaica, the percentage of the labour force with incomes below a constant real poverty line actually increased.

Relative Income Inequality. Inequality is at low to moderate levels in the four Asian economies. Taiwan in fact has the lowest Gini coefficient of any developing economy. During the 1960s, inequality declined in all four economies. However, the 1970s exhibit a mixed record. On the one hand, inequality continued to fall in Taiwan. On the other, inequality apparently rose in Korea, though the data supporting this conclusion are open to serious question. In between are 
Singapore and Hong Kong. In Singapore, inequality was effectively unchanged between 1975 and 1980. In Hong Kong, two studies have reached opposite conclusions, one reporting a small decline in inequality from 1971 to 1976 , the other reporting an increase in inequality from 1971 to 1976 and again from 1976 to 1981 . Regardless of which study is given more weight, the change in overall income inequality in Hong Kong was not large.

In the Caribbean economies, inequality is at much higher levels than in the four Asian economies. Inequality fell in Trinidad and Tobago in the early 1970s; more recent information is not yet available. In Jamaica, inequality increased to even higher levels.

Summary. The micro dimensions of economic growth in these seven economies track their macro performances rather well.

\section{Interactions}

In this section, I explore interactions between trade policy, wage policy, growth, employment, and income distribution. I start with wage policy.

Labour markets in developing economies in different parts of the world are analysed differently. In East Asia, the dominant paradigm is labour market competition. It is widely-held that wages in East Asia are determined by supply and demand, and adjust when necessary in order to clear labour markets. Elsewhere, the paradigm is markedly different. The dominant view is that wages in Africa, Latin America, the Caribbean, and South Asia lie well above the marketclearing level, at least in some sectors of the economy. It is no accident that the early studies of 
wage structure in developing countries ${ }^{1}$ and the models of wage gap unemployment ${ }^{2}$ excluded East Asia. The reason is simple: wage structure is less of an issue in East Asia. ${ }^{3}$

Why is this? One reason is that wages are much less dispersed in East Asia than elsewhere. The key sector to focus on is manufacturing, since growth of manufacturing exports is the driving force behind the East Asian economies' economic growth. In Hong Kong, Korea, Singapore, and Taiwan, the manufacturing wage is about $20 \%$ higher than the agricultural wage. By contrast, in Jamaica, wages are more than twice as high in manufacturing as in agriculture. ${ }^{4}$ And the same observation - that wages are at least twice as high in manufacturing as in agriculture — holds for many other countries where the data permit intersectoral wage differentials to be calculated.

What explains the differences? The answer, I hypothesise, lies in the wage-setting mechanisms at work in various parts of the world. Four institutional forces, singly or in combination, have potent influences on manufacturing wages in the Caribbean as in other countries outside East Asia. ${ }^{5}$ Minimum wage laws are commonplace and when enforced cause wages to be higher than they otherwise would be. Labour unions often are very strong. At times, this is because of the close association between organised labour and the political party in power. Other times, it is because labour unions are encouraged as a means of achieving higher wages for

\footnotetext{
${ }^{1}$ See, for example, Reynolds (1965, 1969), Turner (1965) Berg (1966, 1969), Smith (1967), Knight (1967), Eriksson (1970) Thormann (1970), Todaro (1971), Turnham (1971), Gregory (1974), and Watanabe (1976).

${ }^{2}$ Harris and Todaro (1970), Tidrick (1975), Todaro (1976).

${ }^{3}$ Says Starr (1981, pp. 12-3): 'Although minimum wage regulation has gradually become more widespread in the Asian region, there are still a number of countries that have not introduced it at all (Hong Kong, the Republic of South Korea and Singapore) or only on a very limited scale...' Presumably, Starr did not mention Taiwan, because his book is published by the ILO and the ILO does not permit mention of Taiwan in its publication.

${ }^{4}$ I focus on Jamaica because of the better data on wage structure there than in Trinidad and Tobago and Barbados.

${ }^{5}$ See, for instance, the references cited on the previous page, especially Tidrick's work based on Jamaica.
} 
workers. Government pay policy often sets the pattern of wages for the rest of the economy, and those in charge have a propensity to pay high wages to all government workers (including themselves). Lastly, multinationals often pay high wages, partly to maintain parity between expatriate and local employees, and partly (in some instances) to appear to be good corporate citizens and thereby to avoid expropriation or expulsion.

Now, the striking feature about wage-setting in Hong Kong, Korea, Singapore, and Taiwan is the absence of such institutional forces. Economic development in those economies has been based on low labour costs. These four economies recognised that is they were first to penetrate and then to hold their positions in world markets, they would have to do so on the basis of price, taking advantage of their abundant supplies of labour. Accordingly, they pursued a variety of policies which had the effect of restraining wage growth. The four institutional forces causing higher-than-market-clearing wages elsewhere - trade unions, minimum wage laws, government pay policy, and multinational corporations - do not play a role in market wage settling in the four Asian economies. Though trade unions bargain over wages, only in Hong Kong do they do so free of government restraint. Minimum wage laws are on the books in some of the countries, but the minimum wage is below the market wage and is therefore irrelevant. Government pay policy in each country is to follow the private sector, not lead it as in other developing regions, especially Africa. And multinationals too follow market forces. ${ }^{1}$

Taken together with the data in the previous section, this examination of wage policy suggests that in these seven export-oriented economies, high economic growth, excellent employment and income distribution performance, and strict wage policy coexist, as do their opposites in these seven export- oriented economies. Now, seven countries' experience is a small

\footnotetext{
${ }^{1}$ In Taiwan, for example, multinationals pay the same wages as indigenous firms.
} 
data base for empirical study, and one should be careful not to over generalise. ${ }^{1}$ Nonetheless, the evidence seems to suggest strongly that the associations are not merely coincidental.

I see the differences in wage-setting processes — supply and demand in the East Asian NICs, institutional wage determination elsewhere - as a major reason for their differential rates of economic success. For obvious reasons, higher wages raise input costs, and this is likely to result in reduced exports and hence lower output, unless either (i) higher wages cause productivity to rise and/or (ii) the wage bill increases so much that domestic demand increases faster than foreign demand falls off. The employment effects of the different wage setting mechanisms are easily understood in terms of simple supply and demand analysis. The wage elasticity of demand for labour would be especially high in an open economy, because higher costs (unless accompanied by higher productivity) may result in large losses of export sales. Next, consider inequality. Quite simply, if everyone in the labour force is employed at a marketclearing wage, inequality is less than if some are employed at higher-than- market-clearing wage and others are unemployed and earn nothing. So unless this is offset by losses of profits among those at the top of the income distribution, inequality will rise. Finally, what about poverty? Those people who would have been employed when the wage is at the market-clearing rate but are not employed when the wage is higher are poorer than before. But those who remain employed are less poor than before, and may even escape from poverty altogether. Most poverty indices would give heavy weight to the increasing number of zero-income people, and so would register an increase in poverty resulting from a higher-than-market clearing wage.

I conclude that the functioning of labour markets, especially the wage-setting mechanism, is a causal factor determining the success or failure of export-led growth. Whether an export-

\footnotetext{
${ }^{1}$ In future work, I plan to extend this analysis to a larger sample of countries.
} 
oriented trade strategy dominates or is dominated by an internally-oriented one depends in part on the country's choice of wage policy. If a country adopts a lenient wage policy, and if the lenient wage policy renders the country's exports unprofitable in world markets, then an exportoriented development strategy may harm the development effort. An export orientation may make a bad situation worse. If the wage policy cannot be changed, an inward-oriented trade policy may be called for.

Formal models developing this proposition will appear in a subsequent paper.

\section{Conclusions}

The current conventional wisdom in development economics has it that a switch from import-substitution industrialisation to an export-oriented trade and industrialisation policy is necessary for successful development. ${ }^{1}$ How often one hears the advice these days: To develop successfully, do what Taiwan (or Korea or Singapore or Hong Kong or Japan) did.

The advocacy of an export-oriented trade policy presupposes an essential condition: the ability to export profitably in world markets if an export orientation is followed. This may be undermined by wage policy. The seven economies analysed in this paper all pursued exportoriented trade strategies but differed in respect to wage policy. After examining their experiences, I conclude:

(1) Changes in employment and income distribution parallel changes in aggregate economic growth in the seven economies examined here. In the rapidly-growing economies, full employment was achieved, the mix of employment was upgraded, real wages rose, absolute

\footnotetext{
${ }^{1}$ See, for example, Krueger (1980; 1981), Chenery, (1980), Balassa (1982), and Ranis (1981).
} 
poverty diminished, and relative inequality remained at low to moderate levels. Contrariwise, slow or negative aggregate growth was accompanied by correspondingly slow or negative changes in employment and income distribution conditions.

(2) Of the seven economies, those that grew rapidly and achieved gains in employment and income distribution also pursued relatively strict wage policies. Contrariwise, lenient wage policies are found in the countries with fair or poor growth, employment, and income distribution performances.

(3) The observed empirical patterns are not unexpected. Whether an export-oriented trade strategy dominates or is dominated by an inward- oriented trade strategy may well depend causally on a country's choice of wage policy.

This approach should be extended in the future in a number of directions: more in-depth institutional analysis of labour market policies in the seven economies considered here, examination of additional countries' experiences, and construction of formal theoretical models. 
Table 1

\section{Table I}

Six Countries: Growth and Poverty Change

\begin{tabular}{lll}
\hline \multicolumn{1}{c}{ Poverty } & \multicolumn{2}{c}{ Growth } \\
\cline { 2 - 3 } Increasing & \multicolumn{1}{c}{ High } & \multicolumn{1}{c}{ Low } \\
Decreasing & $\begin{array}{l}\text { Philippines } \\
\text { Taiwan } \\
\text { Costa Rica } \\
\text { Brazil }\end{array}$ & Sri Lanka \\
\hline \hline
\end{tabular}


Table 2

\section{Table 2}

Six Countries: Growth and Inequality Change

\begin{tabular}{|c|c|c|}
\hline \multirow[b]{2}{*}{ Inequality } & \multicolumn{2}{|c|}{ Growth } \\
\hline & High & Low \\
\hline Increasing & $\begin{array}{l}\text { Philippines } \\
\text { Brazil }\end{array}$ & - \\
\hline Decreasing & $\begin{array}{l}\text { Costa Rica } \\
\text { Taiwan }\end{array}$ & $\begin{array}{l}\text { Sri Lanka } \\
\text { India }\end{array}$ \\
\hline
\end{tabular}


Table 3

Table 3

Changes in Labour Market Conditions and Income Distribution in Seven Small Open Economies

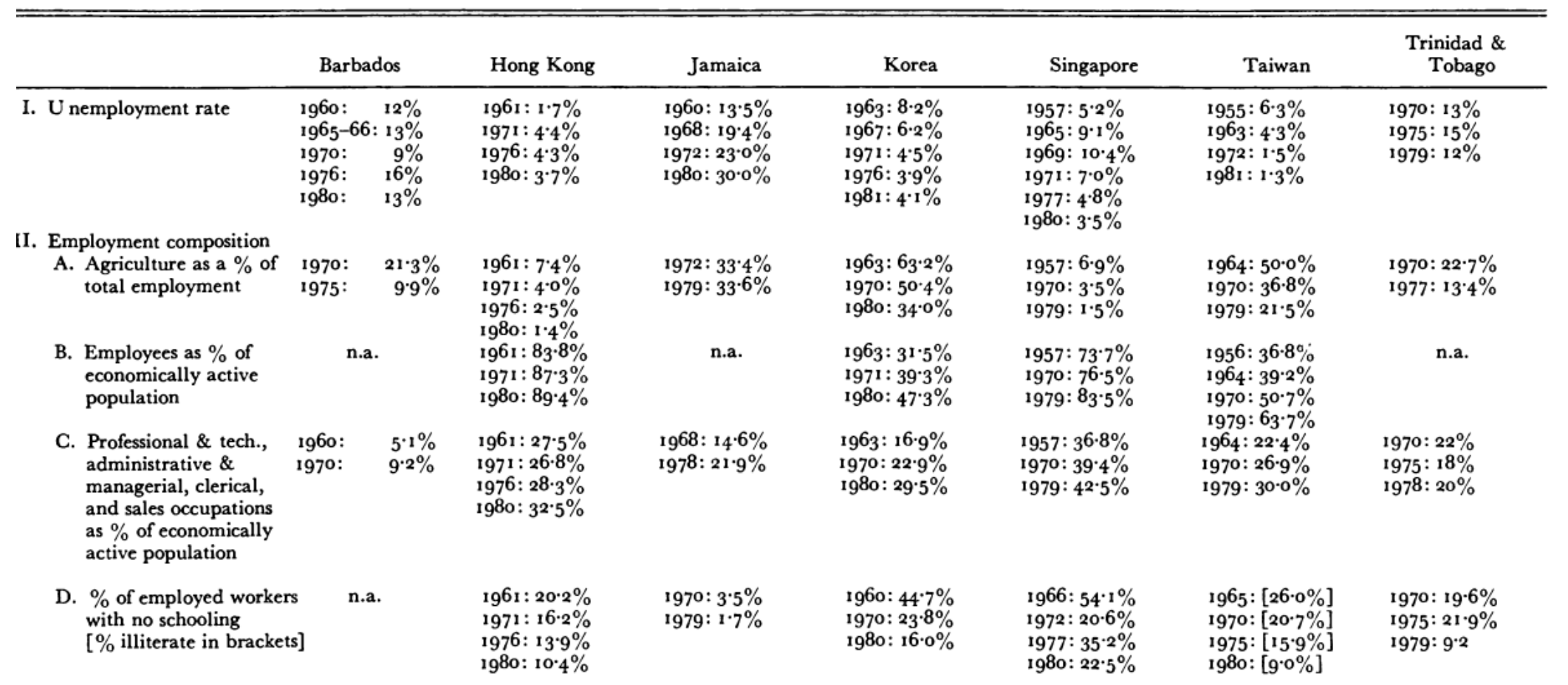


Table 3 (continued)

III. Real wages or earnings

IV. Poverty

$$
\begin{aligned}
& \text { Index of avg. } \\
& \text { real wage, } 1976 \\
& \text { = } 100: \\
& 1976: 100 \cdot 0 \% \\
& 1980: 125 \cdot 7 \%
\end{aligned}
$$

$$
\begin{aligned}
& \text { Index of avg. } \\
& \text { real manufac- } \\
& \text { turing wage, } \\
& 1948=100: \\
& 1960: 105 \\
& 1965: 157 \\
& 1970: 167 \\
& 1975: 194 \\
& 1980: 253
\end{aligned}
$$

n.a.
$\%$ of households with annual in- comes less than $\mathrm{HK} \$ 30 \mathrm{OO}$, in constant 1966 HK\$: $1966: 18 \%$ $1971: 11 \%$

$\begin{array}{ll}\text { n.a. } & 1966: 0.487 \\ & 1971: 0.411 \\ & 1976: 0.435 \\ 1981: 0.447\end{array}$

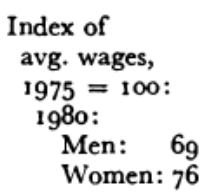

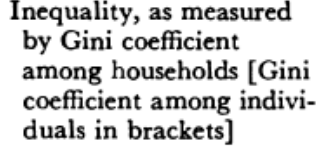
1976: $7 \%$

$\%$ of labour force with weekly incomes less than $\mathrm{J} 820$, in constant $1973 \mathrm{~J}$ \&: 1968: $70 \%$ 1973: $72 \%$

1979: $80 \%$

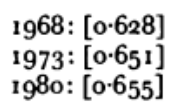

1973: [0.651] $1981: 0.447$

$$
\begin{aligned}
& \text { Index of real } \\
& \text { earnings, } 1975 \\
& \text { = } 100: \\
& \text { 1966: } 52 \\
& 1972: 88 \\
& 1978: 154 \\
& 1980: 159
\end{aligned}
$$

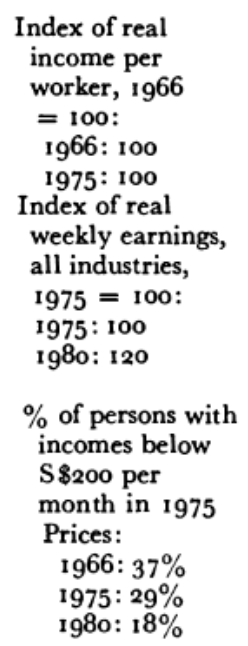

$\%$ of persons with incomes below

S\$200 per month in 1975

Prices:

1966: $37 \%$

1975: $29 \%$

1980: $18 \%$

1970: $23 \%$

1976: $15 \%$

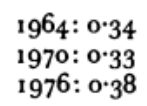

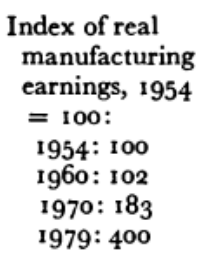

$\%$ of households with incomes below specified figure in specified year: NT \$20,000 $1964: 35 \%$ 1972: $10 \%$ NT $\$ 40,000$ $1964: 80 \%$ 1972: $35 \%$

1966: [0*499]

$1975:[0 \cdot 452]$ 1980: [0.455]
Early 1950's: 0.5 1968-72:0.3 $1976-78: 0 \cdot 27$
Index of real weekly earnings of production workers, 1971 $=100$ :

1971: 100 1978: 124

n.a. Time series information not available. Sources: Fields $(1981 ; 1982)$. 


\section{References}

Balassa, Bela. (1982). Development Strategies in Semi-Industrial Economies, Baltimore: Johns Hopkins University Press.

Berg, Elliot. (1966). 'Major issues of wage policies in Africa'. In Ross, A. M., ed., Industrial Relations and Economic Development, New York: Macmillan.

------ (1969). 'Wage structure in less developed countries'. In Smith, A. D., ed., Wage Policy Issues in Economic Development, London: Macmillan.

Chenery, Hollis B. (1980). 'Interactions between industrialization and exports'. American Economic Review. (May).

Choo Hakchung. (1980). ‘Economic growth and income distribution'. In Chong Kee Park, ed., Human Resources and Social Development in Korea, Seoul: Korea Development Institute.

Chow, Steven and Papanek, Gustav. (1981). 'Laissez faire, growth, and equity - Hong Kong'. Economic Journal. (June).

Crosswell, Michael. (1981). 'Growth, poverty alleviation, and foreign assistance'. AID Discussion Paper No. 39, (August).

Eriksson, John. (1970). 'Wage change and employment growth in Latin American industry'. Research Memorandum No. 36, Centre for Development Economics, Williams College.

Fields, Gary S. (1980). Poverty, Inequality, and Development, Cambridge and New York: Cambridge University Press. 
----- (1981). 'Growth, employment, inequality and poverty in Trinidad and Tobago, Barbados, and Jamaica'. Cornell University, Department of Labor Economics Working Paper No. 41, (December) .

----- (1982). 'Industrialization and employment in Hong Kong, Korea, Singapore, and Taiwan'. Cornell University, Department of Labor Economics Working Paper No. 42, Revised Version, (May).

Galenson, Walter. (1979). 'Economic growth, poverty, and the international agencies'. Journal of Policy Modelling, vol. no. 1 (2).

Gregory, Peter. (1974). 'Wage structure in Latin America'. The Journal of Developing Areas, vol. 8, (July), pp. 557-8o-

Harris, John andTodaro, Michael. (1970). 'Migration, unemployment, and development: a two sector analysis'. American Economic Review. (March).

Knight, J. B. (1967). 'The determination of wages and salaries in Uganda'. Bulletin of the Oxford Institute of Economics and Statistics. (August), vol. 29 (3) pp. 233-64.

Krueger, Anne (1980) 'Trade policy as an input to development'. American Economic Review. (May).

----- (1981). Trade and Employment in Developing Countries, Chicago: The University of Chicago Press.

Ranis, Gustav (1981). 'Challenges and opportunities posed by Asia’s super-exporters: implications for manufactured exports from Latin America'. Quarterly Review of Economics and Business. (Summer).

Reynolds, Lloyd G. (1965). 'Wages and employment in a labour-surplus economy'. American Economic Review. (March). 
------ (1969). 'Relative earnings and manpower allocation in developing economies'. Pakistan Development Review. (Spring).

Smith, A. D. (1967). 'Minimum wages and the distribution of income with special reference to developing countries'. International Labour Review. (August), pp. 129-50.

Starr, Gerald. (1981). Minimum Wage Fixing, Geneva: International Labour Office.

Thormann, Peter. (1970). 'The rural-urban income differential and minimum wage fixing criteria'. International Labour Review, (August).

Tidrick, Gene M. (1975). 'Wage spillover and unemployment in a wage-gap economy: the Jamaican case'. Economic Development and Cultural Change.

Todaro, Michael P. (1971). 'Income expectations, rural-urban migration and employment in Africa'. International Labour Review. (November).

------ (1976). Internal Migration in Developing Countries, Geneva: International Labour Office.

Turner, H. A. (1965). 'Wage trends, wage policies and collective bargaining: the problems for underdeveloped countries', University of Cambridge, Department of Applied Economics, Occasional Papers, No. 6 (Cambridge University Press).

Turnham, David. (1971). The Employment Problem in Less Developed Countries, Paris: Development Centre of the Organisation for Economic Cooperation and Development.

Watanabe, S. (1976). 'Minimum wages in developing countries: myth and reality'. International Labour Review, (May-June).

Worrell, DeLisle. (1981). 'An economic survey of Barbados, 1946-80'. Central Bank of Barbados, Research Department, (December). 